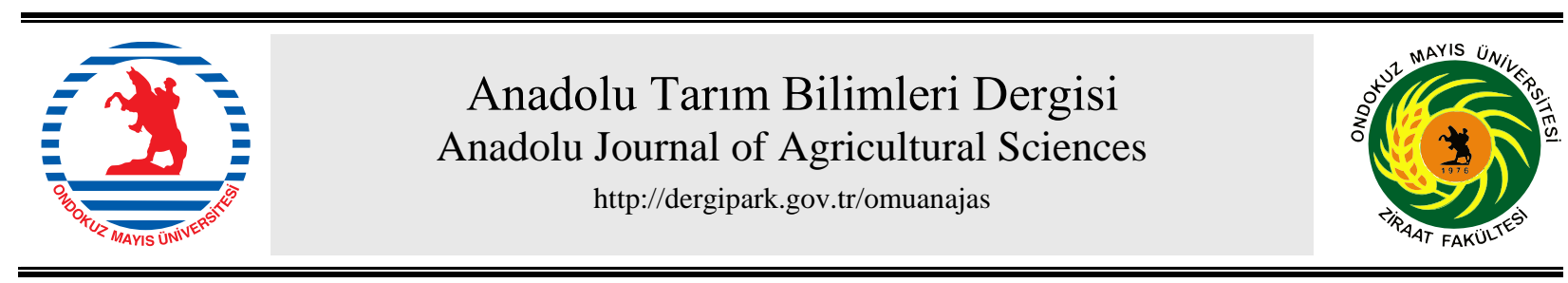

\title{
Farklı Sulama Suyu Tuzluluğunun Frenk Soğanı (Allium schoenoprasum) Bitkisinin Yaprak Mineral İçeriği Üzerine Etkisi ve Tepki Yüzey Metodolojisi ile Modellenmesi
}

\author{
DMehmet Sait Kiremit ${ }^{\mathrm{a}}$, $\odot$ Hakan Arslan ${ }^{\mathrm{a}^{*}}$ \\ ${ }^{\mathrm{a}}$ Ondokuz Mayıs Üniversitesi, Ziraat Fakültesi, Tarımsal Yapılar ve Sulama Bölümü, Samsun, Turkey
}

*Sorumlu yazar/corresponding author: hakan.arslan@omu.edu.tr

Geliş/Received 03/07/2020 Kabul/Accepted 10/09/2020

\begin{abstract}
ÖZET
Küresel iklim değişimi, tarımsal üretimde geleneksel olmayan suların sulamada kullanılmasını zorunlu hale getirmiştir. Ancak, ekolojik dengenin korunması ve sürdürülebilir tarımsal üretimi sağlamak için geleneksel olmayan suların en akılcı şekilde kullanılması gerekmektedir. Bu çalışmada, 6 farklı sulama suyu tuzluluğunun $\left(0.38 \mathrm{dSm}^{-1}\right.$ (çeşme suyu), 1.0, 2.0, 4.0, 6.0 ve $\left.8.0 \mathrm{dSm}^{-1}\right)$ frenk soğanı bitkisinin yaprak mineral içeriği üzerine etkileri araştırılmıştır. Çalışma, tesadüf bloklar deneme desenine göre 4 tekerrürlü olarak saksılarda yürütülmüştür. Deneysel olarak tespit edilen yaprak mineral içeriği değerlerinin optimizasyonu cevap yüzey metodolojisi kullanılarak tarihsel veri yöntemine göre modellenmiştir. Elde edilen verilere göre, sulama suyu tuzluluğu $0.38 \mathrm{dSm}^{-1}$ ' den $8.0 \mathrm{dSm}^{-1}$, e kadar arttığında, yaprak $\mathrm{Na}^{+}$içeriği $\% 63.85$ oranında artmıştır, yaprak $\mathrm{K}^{+}$, $\mathrm{Ca}^{+2}$ içeriği ve $\mathrm{K}^{+} / \mathrm{Na}^{+}$oranı sırasıyla \%48.8, \%30.93 ve \%81.67 oranında azalmıştır. Ayrıca, yaprak $\mathrm{Na}^{+}$içeriğinde bir birimlik artış oransal verimde \%44.4 oranında azalıșa neden olmuş, $\mathrm{K}^{+}, \mathrm{Ca}^{+2}, \mathrm{~K}^{+} / \mathrm{Na}^{+}$parametrelerinde bir birimlik artış oransal verimde \%42.4, \%19.2 ve \%11.2 oranında artmıştır. Yaprak $\mathrm{K}^{+}, \mathrm{Ca}^{+2}$ ve $\mathrm{Na}^{+}$mineral içerikleri ile oransal verim arasındaki korelasyon katsayıları sırasıyla $0.89,0.87$ ve -0.94 olduğu tespit edilmiştir. Frenk soğanı için optimum yaprak mineral içerikleri sulama suyu tuzluluğunun $0.48 \mathrm{dSm}^{-1}$ ve toprak tuzluluğunun $0.81 \mathrm{dSm}^{-1}$ olduğu koşullarda gözlemlenmiştir. Sonuç olarak, bitkiler için tuzlu su ve toprak koşullarında optimum yetiştirme koşullarının belirlenmesi amacıyla yüzey tepki metodolojisinin kullanılması hem yüksek verim ve kaliteli ürün elde edilmesinde hem de toprak tuzluluğunun kontrol edilebilmesi içinde yararlı olacaktır.
\end{abstract}

\section{Effects of the Irrigation Water Salinity on Leaf Mineral Content of Chives (Allium schoenoprasum) and Modelling with Response Surface Methodology}

\section{ABSTRACT}

Global climate change has made obligatory to use non-conventional waters for irrigation in agricultural production. However, non-conventional waters should be used in a rational way to maintain ecological balance and to ensure agricultural production. In this study, the effects of 6 different irrigation water salinity $\left(0.38 \mathrm{dSm}^{-1}\right.$ (tap water), 1.0, 2.0, 4.0, 6.0, and $\left.8.0 \mathrm{dSm}^{-1}\right)$ on leaf mineral content of chives were investigated. The trial was carried out in pots using a randomized plot design with four replicates. Optimization of the experimentally determined leaf mineral content values was modeled according to the historical data method using the response surface methodology. Based on the obtained results, as the salinity of irrigation increased from $0.38 \mathrm{dSm}^{-1}$ to $8.0 \mathrm{dSm}^{-1}$, leaf $\mathrm{Na}^{+}$content increased by $63.85 \%$, while leaf $\mathrm{K}^{+}, \mathrm{Ca}^{+2}, \mathrm{~K}^{+} / \mathrm{Na}^{+}$ratio decreased by $48.8 \%$, 30.93\%, and $81.67 \%$, respectively. Moreover, per unit increase in leaf $\mathrm{Na}+$ content decreased the relative yield by $44.4 \%$, while per unit increase in $\mathrm{K}^{+}, \mathrm{Ca}^{+2}, \mathrm{~K}^{+} / \mathrm{Na}^{+}$parameters increased the relative yield by $42.4 \%, 19.2 \%$, and $11.2 \%$ respectively. The correlation coefficients of the between leaf $\mathrm{K}^{+}, \mathrm{Ca}^{+2}, \mathrm{Na}^{+}$contents, and relative yield were found to be 0.89, 0.87, -0.94 , respectively. Optimum leaf mineral contents for chives were observed at the irrigation water salinity $0.48 \mathrm{dSm}^{-1}$ and soil salinity $0.81 \mathrm{dSm}^{-1}$ conditions. Consequently, using response surface
Anahtar Sözcükler: Tuz stresi

$\mathrm{K} / \mathrm{Na}$ oran 1 Modelleme Tuzluluk yönetimi Tepki yüzey
Keywords: Salinity stress $\mathrm{K} / \mathrm{Na}$ ratio Modeling Salinity management Response surface 
methodology for the determination of optimum growing conditions of crops under saline water-soil conditions will be helpful not only for high yield and quality products but also for controlling soil salinity.

\section{Giriş}

Dünya nüfusunun hızla artarak 2050 yılında 10 milyara ulaşması beklenmektedir (Searchinger ve ark., 2019). Bu nedenle 2050 yilında artan nüfusun gida ihtiyacını karşılamak için gıda ve besin kaynaklarını $\% 70$ oranında arttırılması gerekmektedir (Gill ve Tuteja, 2010). İklim değişimi sonucunda, yağış rejiminde meydana gelen değişimler, düşük kaliteli suların tarımsal üretimde kullanılmasını zorunlu kılmaktadır (Zandalinas ve ark., 2018) Bu durum ise bitkilerin yapısında morfolojik, fizyolojik ve moleküler değişimlere neden olarak çeşitli biyotik ve abiyotik streslere yol açmaktadır (Sassine ve ark., 2020). Ayrıca, bu stresler bitkilerin verim miktarını ve kalitesini önemli derecede olumsuz yönde etkilemektedir (Sassine ve ark., 2020). Tuzluluk stresi abiotik stresler arasında, bitkilerin morfolojik ve fizyolojik gelişimini kısıtlayan en önemli çevresel faktörlerden birini oluşturmaktadır. Günümüzde, tuzlu sular, drenaj suları ve atık suların tarımsal üretimde kullanılması sonucunda tuzlu toprak arazileri artmakta ve bunun sonucunda ise, ekilebilir arazi kayıplarına neden olmaktadır (Machado ve Serralheiro, 2017; Zorb ve ark., 2018). FAO (2018) raporuna göre, kurak ve yarı kurak bölgelerde her gün $20 \mathrm{~km}^{2}$ 'den fazla alanda/arazide tuzlulaşma oluşmaktadır.

Tuzluluk stresi, bitki gelişimi ve büyümesi ile bitki hücrelerinde ozmotik ve iyon dengelerini bozarak, hücre zarlarındaki besin maddeleri ve metabolit dengesizliğini önemli derecede değiştirerek hücresel gelişimi azaltmaktadır (Luo ve Liu, 2011; Amjad ve ark., 2015). Tuzluluk stresinin, ozmotik ve spesifik iyon etkileri sonucunda bitki su alımını azaltarak, spesifik iyon toksitesine ve bitkilerde $\mathrm{K}^{+}$eksikliğine neden olmaktadır (Shabala ve Cuin, 2008; Sheldon ve ark., 2017). Bununla birlikte toprak tuzluluğunun artması ile birlikte, toprağın ozmotik basıncının yükselmesi ile bitkilerin su alımı ile tuz minerallerinin bitki dokularına taşınmasına ve $\mathrm{Na}^{+}$ve $\mathrm{CI}^{-}$toksitesine yol açmaktadır (Sheldon ve ark., 2017). Dünya genelinde, sulama sularının tuz içeriği değişkenlik göstermektedir. Ancak, birçok sulama suyunda $\mathrm{Na}^{+}, \mathrm{Ca}^{+2}, \mathrm{Mg}^{+2}$ baskın katyon iyonlarını oluşturmakta, $\mathrm{CI}^{-}, \mathrm{SO}_{4}{ }^{-2}$ ve $\mathrm{HCO}_{3}{ }^{-}$iyonları ise baskın anyonları oluşturmaktadır (Grattan ve Grieve, 1998). Literatür incelendiğinde, tuzlu su çalışmalarında en çok NaCI tuzu kullanılmaktadır (Baath ve ark., 2017). Bitkilerde aşırı $\mathrm{Na}^{+}$alımı, iyon dengesizliğine neden olarak, $\mathrm{Ca}^{+}, \mathrm{Mg}^{+2}$ ve $\mathrm{K}^{+}$alımınının azalmasına, dolayısıyla bitkide fotosentez ile $\mathrm{K}^{+} / \mathrm{Na}^{+}$oranının azalmasına ve sonuç olarak bitkide enzimatik reaksiyonların engellenmesine neden olmaktadır (Zhu, 2007).
Literatür incelendiğinde, sulama suyu tuzluluğu ve toprak tuzluluğu faktörlerinin ayrı ayrı yaprak mineral içeriği üzerine etkisi birçok araştırmacı tarafından incelenmiştir (Ünlükara ve ark., 2010; Akça ve ark., 2012; Qiu ve ark., 2019; Tanveer ve ark., 2020). Bu iki faktör göz önünde bulundurularak frenk soğanı bitkisinin yaprak mineral içeriği üzerine etkileri incelenmemiştir. Bu nedenle, sulama suyu tuzluluğu ve toprak tuzluluğu faktörlerin yaprak mineral içeriği üzerine tekli ve çoklu etkilerini incelemek amacıyla tepki yüzey metodolojisi (TYM) kullanılmıştır. TYM, belirli bir çalışmada bağımsız faktörlerin tekli veya çoklu interaksiyonlarının bağımlı değişkenler üzerinde etkilerini ve bağımlı değişkenlerin elde edilmesinde optimum koşulların belirlenmesi için kullanılan matematiksel ve istatistiksel bir araçtır (Myers ve Montgomery, 2002; Pilkington ve ark., 2014). Tarımsal üretimde, TYM birçok bitkinin üretim maliyetini azaltmak için etkin bir şekilde kullanılmaktadır (Wang ve ark., 2019).

Farklı sulama suyu tuzluluğunun frenk soğanı bitkisinin verim, bitki su tüketimi, toprak tuzluluğu ve yaprak mineral içeriği üzerine etkilerinin incelendiği bu çalışmada ayrıca, sulama suyu tuzluluğu ve toprak tuzluluğu faktörleri kullanılarak yüzey tepki metodolojisi ile yaprak mineral içeriği tahmininde kullanılma olasılığının belirlenmesi amaçlanmıştır. Buna ilaveten, frenk soğanı bitkisinin yaprak mineral içeriği parametrelerinden hangisinin verim üzerinde daha etkili olduğu ve bu parametrelerin frenk soğanı bitkisinin tuza karşı toleransının belirlenmesinde kullanılabilirliği belirlenmeye çalışılmıştır.

\section{Materyal ve Yöntem}

\subsection{Deneme alanı ve yetiştirme koşulları}

$\mathrm{Bu}$ çalışma, Ondokuz Mayıs Üniversitesi, Ziraat Fakültesi, Araştırma ve Deneme Uygulamaları arazisinde dört tarafı açık ve yağmurdan korunaklı 120 $\mathrm{m}^{2}$ 'lik alanda Mayıs - Eylül 2016 tarihleri arasında yapılmıştır. Çalışma periyodu boyunca, ortamın sıcaklık ve bağıl nem değerleri, çalışma alanın ortasında olacak şekilde $2 \mathrm{~m}$ yüksekliğe yerleştirilen elektronik veri kaydedici (KISTOCK KMO Data logger) ile ölçülmüştür. Deneme süresince, sıcaklık değeri $24.3{ }^{\circ} \mathrm{C}$ ile $36.0{ }^{\circ} \mathrm{C}$ arasında değişim gösterirken, bağ 11 nem değeri ise $\% 45.3$ ile $\% 68.2$ arasında değişim gösterdiği tespit edilmiştir.

Farklı sulama suyu tuzluluğunun frenk soğanı bitkisi üzerine etkilerini belirlemek amacıyla saksı çalışması yürütülmüştür. $\mathrm{Bu}$ amaçla, çalışmada polietilenden yapılmış, $31 \mathrm{~cm}$ derinlik, $36 \mathrm{~cm}$ taban çap ve $38 \mathrm{~cm}$ üst 
çapa sahip olan saksılar kullanılmıştır. Denemede kullanılan toprak $\% 52.3 \mathrm{kum}, \% 9.4$ kil ve $\% 38.3$ silt içeriğine sahip tınlı topraktır. Toprağın kimyasal özellikleri incelendiğinde ise, $\mathrm{pH}$ 's1 $8.28, \mathrm{EC}\left(\mathrm{dSm}^{-1}\right)$ 0.63 , organik madde içeriği (\%) $1.24, \mathrm{P}_{2} \mathrm{O}_{5}(\mathrm{~kg} / \mathrm{ha}) 40$, $\mathrm{K}_{2} \mathrm{O}$ (kg/ha) 500 olarak tespit edilmiştir. Denemede kullanılan toprak hava kuru hale gelene kadar yağmurdan korunaklı alanda kurutulmuş ve daha sonra 4 mm'lik gözenek hacmine sahip elek ile elenmiştir. Saksilar toprak ile doldurulmadan önce, drenaj1 sağlamak amacıyla her bir saksının tabanına $5 \mathrm{~kg}$ mucur konulmuştur ve daha sonra elenmiş topraktan $32 \mathrm{~kg}$ toprak ilave edilmiştir.

Çalışmada, Allium familyasında yer alan frenk soğanı veya yaprak soğanı adı ile bilinen bitki çeşidi kullanılmıştır. Her bir saksıya 50 adet frenk soğanı tohumu ekilmiştir. Tohumlar çimlenip sürgün oluşturduktan sonra her bir saksı da 25 adet frenk soğanı fidesi olacak ş̧ekilde seyreltme işlemi gerçekleştirilmiştir. Gübreleme, bölge çifçilerinin uygulama miktarları dikkate alınarak yapılmıştır. Tohum ekiminden önce, $1.5 \mathrm{~g}$ fosfor pentaoksit $\left(\mathrm{P}_{2} \mathrm{O}_{5}\right)$ gübresi saksının ilk 5 c'sindeki toprağa uygulanmıştır. Azot gübresi, toplamda 2 defa (1.80 g) uygulanmıştır, Azot ihtiyacının yarısı tohum ekiminden önce (\%46 üre) ve diğer yarısı ise tohum ekimden bir ay sonra uygulanmıştır.

\subsection{Deneme deseni ve sulama suyu tuzluluğu}

Çalışma, tesadüf blokları deneme desenine göre 4 tekerrürlü olarak yürütülmüştür. Bunun için denemede 6 farklı tuz içeriğine $\left(0.38 \mathrm{dSm}^{-1}\right.$ (çeşme suyu), $1.0 \mathrm{dSm}^{-1}$, $2.0 \mathrm{dSm}^{-1}, 4.0 \mathrm{dSm}^{-1}, 6.0 \mathrm{dSm}^{-1}$ ve $8.0 \mathrm{dSm}^{-1}$ ) sahip sulama suları uygulanmıştır. Böylece denemede toplam 24 adet plastik saksı kullanılmıştır. Tuzlu suların hazırlanmasinda ise, $\mathrm{NaCI}, \mathrm{CaCI}_{2}$ ve $\mathrm{MgSO}_{4}$ tuz çeşitleri kullanılmıştır. Tuzlu suların oluşturulması için gerekli olan tuz miktarları QBASIC bilgisayar programı ile hesaplanmıştır. Ayrıca, tuz miktarlarının belirlenmesinde Sodyum Adsorpsiyon Oranı (SAR) değerinin etkisini minimum düzeyde tutabilmek için tüm sularda SAR değeri $<5$ olacak şekilde belirlenmiştir.

Denemeye başlamadan önce her bir saksının tarla kapasitesi belirlenmiştir. Bunun için saksılar toprak yüzeyinden şebeke suyu ile tamamen doyurulmuş ve daha sonra saksı altlarındaki deliklerden meydana gelen drenaj suyu akışı sona erene beklenmiştir. Ayrıca saksı yüzeyinden buharlaşmayı önlemek amacıyla her bir saksının üstü plastik kapak ile kapatılmıştır. Drenaj sona erdikten sonra her bir saksının ağırlığı tartılmış ve o saksının tarla kapasitesi ağırlığ 1 ( $\left.\mathrm{W}_{\mathrm{TK}}\right)$ olarak kabul edilmiştir (Arslan ve ark., 2018).

Konularına göre, her bir saksıya verilecek olan sulama suyu miktarları Eşitlik 1 yardımıyla belirlenmiştir. Sulama işleminden önce saksıların toprak nem içeriği değerlerini belirlemek amacıyla $0.01 \mathrm{~g}$ hassasiyete sahip terazi ile her bir saksının ağırlığı belirlenmiştir.

$$
\mathrm{SSM}=\frac{\frac{\mathrm{W}_{\mathrm{TK}}-\mathrm{W}_{\mathrm{MN}}}{\rho_{\mathrm{W}}}}{1-\mathrm{LF}}
$$

Eşitlikte; SSM; sulama suyu miktarı (L), $\mathrm{W}_{\mathrm{TK}}$; Saksının tarla kapasitesi değeri $(\mathrm{kg}), \mathrm{W}_{\mathrm{MN}}$; Saksının sulama öncesi ağırlığı $(\mathrm{kg}), \mathrm{LF}$; Y 1 kama oranı $(\%), \rho_{\mathrm{w}}$; suyun hacim ağırlığını $(1 \mathrm{~kg} / \mathrm{L})$ ifade etmektedir.

Saksılarda aşırı tuz birikimini önlemek amacıyla yıkama oranı değeri 0.15 olarak alınmıştır (Ayers ve Westcot, 1985). Ayrica her sulamadan sonra her bir saksı altına yerleştirilen plastik kaplarla saksıdan çıkan drenaj suyu miktarı tespit edilmiştir.

Tohumların çimlenmesi ve sürgün çıkışları başlayana kadar tüm saksılar $0.38 \mathrm{dSm}^{-1}$ sulama suyu ile sulanmıştır. Fide boyları $10 \mathrm{~cm}$ 'ye ulaştıktan sonra konularına göre tuzlu su uygulamalarına başlanılmıştır. Keller ve Bliesner (1990) göre yüzlek kök derinliğine sahip sebze bitkilerinden yüksek ve kalite verim elde edilebilmesi için topraktaki elverişli nemin $\% 25$ ile $\% 40$ arasında tüketildiğinde sulama işleminin yapılmasını önermişlerdir. Belirtilen bu durum çalışma periyodu boyunca esas alınarak, çeşme suyu ile sulanan $(0.38$ $\mathrm{dSm}^{-1}$ ) kontrol konusuna ait saksılarda elverişli nem azalma miktarı günlük saksıların tartılması ile tespit edilmiş ve tüketilmesine izin verilen toprak nem içeriği $\% 30$ oranında azaldığında sulama işlemleri gerçekleştirilmiştir. Çalışmada elde edilen bitki su tüketimi değerleri ile ilgili detaylı bilgiler Arslan ve ark., (2018) çalışmasında verilmiştir.

\subsection{Deneme yapılan ölçümler}

Hasat döneminde, her saksıda mevcut olan frenk soğanı yaprakları toprak yüzeyinden kesilerek hasat edilmiştir. Her saksıdan hasat edilen yapraklar tartılarak, g/saksı cinsinden toplam yaprak ağırlığı (verim) elde edilmiştir. Yaprak kuru ağırlı̆̆ belirlenmesinde ise, yapraklar etüvde $70{ }^{\circ} \mathrm{C}$ de sabit ağırlığa gelinceye kadar kurutulmuş ve daha sonra tartılarak $\mathrm{g}$ cinsinden yaprak kuru ağırlığı belirlenmiştir (Arslan ve ark., 2018).

Frenk soğanı yaprak mineral içeriğinin belirlenmesi için, her saksıdan zarar görmemiş yapraklar hasat edildikten sonra çeşme suyu ile yıkanmıştır. Daha sonra saf su ile yıkanarak etüvde $70{ }^{\circ} \mathrm{C}$ 'de sabit ağırlığa gelince kadar kurutulmuştur. Kurutulan örnekler bitki yaprak öğütücüsü ile öğ̈̈tülerek, $0.2 \mathrm{~mm}$ gözenek açıklığına sahip elek ile elenmiştir. Yaprak mineral analizi için 1 gr örnek kullanılmış ve örneklerin analiz için hazırlanmasında Kaçar ve İnal (2010) belirttiği esaslar göz önünde bulundurularak hazırlanmıştır. Örneklerin Na, K, Ca mineral içerikleri alev fotometresi kullanılarak belirlenmiştir.

Çalı̧̧ma periyodu sonunda, hasat işleminden hemen sonra, her saksının orta noktasından olacak şekilde 
toprak örneği alınarak, laboratuvarda kurutulmuş ve daha sonra dövülerek $2 \mathrm{~mm}$ elekten elenmiştir. Elenmiş topraklardan 100 gr örnek alınarak doygun hale gelene kadar saf su ilave edilmiş ve 24 saat boyunca laboratuvarda bekletilmiştir. Daha sonra saturasyon örneklerinin süzüğü 4 atm'lik basınç altında çıkartılmıstır. Elde edilen süzüklerin elektriksel iletkenlik değeri Mettler Toledo EC aleti ile tespit edilmiştir. Ayrıntılı bilgiler Arslan ve ark., (2018) çalışmasında verilmiştir.

\subsection{Istatistiksel analiz}

Çalışmadan elde edilen veriler JUMP 13.2 bilgisayar programı kullanılarak analiz edilmiştir. Farklı sulama suyu tuzluluğu uygulamalarına göre konular arasındaki önemli farklılıklara ilişkin gruplandırma $\mathrm{p}<0.05$ önemlilik düzeyinde LSD Student $t$ testi göre değerlendirilmiştir. Ayrıca, sulama suyu tuzluluğu ile toprak tuzluluğu ve yaprak mineral içerikleri arasındaki ilişkiler bar grafiği ile incelenmiştir. Bar grafiklerindeki, düşey çizgiler konulara ait standart hata değerlerini ifade etmektedir. Oransal verim ile bitki mineral parametreleri arasındaki ilişkilerin belirlenmesinde Microsoft Excel 2019 paket programı kullanılarak regresyon analizleri yapılmıştır.

Yaprak $\mathrm{Na}, \mathrm{K}, \mathrm{Ca}$ ve $\mathrm{K} / \mathrm{Na}$ içerikleri (y) bağıml değişkenleri, sulama suyu tuzluluğu $\left(\mathrm{x}_{1}\right)$ ve toprak tuzluluğu $\left(\mathrm{x}_{2}\right)$ bağımsız değişkenleri kullanarak tepki yüzey metodolojisi (TYM) ile tahmin edilmiştir. TYM, istatistiksel ve matematiksel tekniklerin bir arada kullanıldığı bir yöntemdir. $\mathrm{Bu}$ yöntemde, birçok bağımsız değişken kullanılarak, seçilen bağımsız değişkenlerin bağımlı değişken üzerindeki tepkilerini görmeyi amaçlamaktadır (Myers ve Montgomery, 2002) ve yöntemde bağımlı değişkenler tepki, bağımsız değişkenleri ise faktör olarak değerlendirmektedir. Regresyon denklemlerinin oluşturulmasında, tepki yüzey metodolojisinin özel tasarım yöntemlerinden tarihsel veri tasarımı yöntemi kullanılmıştır. $\mathrm{Bu}$ yöntemde, bağımsız değişkenlerin alt ve üst sınırları kesin olarak belirlendiği için en doğru tepki sonuçlarını vermektedir (Collins ve Seeney, (1999); Vuchkov ve Boyadjieva, (2001)). Bağımlı değişkenlerin tepkileri, ikinci dereceden polinomlar kullanılarak teorik olarak aşağıdaki şekilde ifade edilen kuadratik regresyon ile modellenmiştir. Anlamlı model değişkenleri $\mathrm{p}<0.05$ önemlilik düzeyine göre seçilmiştir.

$Y=\beta_{0}+\beta_{1} X_{1}+\beta_{2} X_{2}+\beta_{3} X_{1} x X_{2}+\beta_{4} X_{1}^{2}+\beta_{5} X_{2}^{2}+$ $\beta_{6} X_{1}^{2} \times X_{2}+\beta_{7} X_{1} \times X_{2}^{2}$

Burada, $\mathrm{Y}=$ tepki değişkeni veya tahmin edilen bağımlı değişkeni $(\mathrm{Na}, \mathrm{K}, \mathrm{Ca}$ ve $\mathrm{K} / \mathrm{Na}), \beta_{0}=$ model sabitesini, $\beta_{1}, \beta_{2}, \beta_{3}, \beta_{4}, \beta_{5}, \beta_{6}, \beta_{7}$ sirasiyla sulama suyu tuzluluğu $\left(\mathrm{EC}_{\mathrm{iw}}\right)$, lineer toprak tuzluluğunun $\left(\mathrm{EC}_{\mathrm{e}}\right)$ lineer etkilerini, kuadratik $\mathrm{EC}_{\mathrm{iw}} \mathrm{xEC_{e }}$ interaksiyon etkisini, kuadratik $\mathrm{EC}_{\mathrm{iw}}{ }^{2}$ etkisini, kuadratik $\mathrm{EC}_{\mathrm{e}}{ }^{2}$ etkisini, kuadratik $\mathrm{EC}_{\mathrm{iw}}{ }^{2} \mathrm{xEC}$ interaksiyon etkisini,

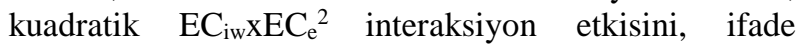
etmektedir (Montgomery, 2008). Regresyon modelleri, çoklu belirleme katsayısı $\left(\mathrm{R}^{2}\right)$, tahmin edilen belirleme katsayıs1 $\left(\mathrm{R}^{2}\right)$, Varyasyon Katsayısı (VK), uyum yetersizliği, yeterli hassasiyet değerlerine göre değerlendirilmiştir. YTM'de modellere ait uyum yetersizliği değerinin istatistiksel olarak $\mathrm{p}>0.05$ 'den büyük olması istenir. Bu durum ise, modele ait bağımsız değişkenlerin uygun olup olmadığını ifade etmektedir (Myers ve Montgomery, 2002). Modele ait yeterli hassasiyet değeri, tepki değerlerine ait tahmin edilen değerlerin aralığını ortalama tahmin hatası ile karşılaştırır ve konular arasındaki farklılıkları ayırt etme açısından yeterli hassasiyet değerinin 4'ten büyük olmas1 istenir (Myers ve Montgomery, 2002). Regresyon denklemleri ve grafikler Design Expert 11.0 bilgisayar programı kullanılarak elde edilmiştir.

\section{Bulgular ve Tartışma}

$\mathrm{Bu}$ çalışmada, farklı sulama suyu tuzluluğunun frenk soğanı bitkisinin yaprak mineral içerikleri üzerine etkileri incelenmiştir. Çalışmada, sulama suyu tuzluluğunun toprak tuzluluğu, yaprak yaş ağırlığı, yaprak $\mathrm{Ca}, \mathrm{K}, \mathrm{Na}, \mathrm{K} / \mathrm{Na}, \mathrm{Ca} / \mathrm{Na}, \mathrm{K} / \mathrm{Ca}$ parametreleri üzerine istatistiksel olarak $\mathrm{p}<0.01$ önemlilik düzeyinde etkili olduğu tespit edilmiştir (Şekil 1 ve Şekil 2).

\subsection{Toprak tuzluluğu ve verim}

Çalışma kapsamında, sulama suyu tuzluluğu arttıkça, toprak tuz içeriği artmıştır (Şekil 1b). En yüksek toprak tuzluluğu değeri $8.27 \mathrm{dSm}^{-1}$ ile T5 konusunda elde edilirken, en düşük değer ise $1.01 \mathrm{dSm}^{-1}$ ile T0 konusunda belirlenmiştir. Bir başka ifade ile, toprak tuzluluğundaki artış, sulama sularının içerisindeki tuz miktarı ve uygulanan sulama suyu miktarı arttıkça, toprak içerisinde biriken tuz miktarını artırmaktadır. Qiu ve ark. (2018) çalışmalarında, toprak profilinde tuz birikimi ile sulama suyunun tuz içeriği arasında doğrusal bir ilişki olduğunu ifade etmişlerdir.

Farklı sulama suyu tuzluluğuna göre frenk soğanı bitkisinin yaprak yaş ağırlığı (verim) değerlerinde istatistiksel olarak önemli farklılıklar oluşmuştur. Sulama suyu tuz içeriği arttıkça frenk soğanı bitkisinin verim değerleri negatif olarak etkilenmiştir. En yüksek verim $345.42 \mathrm{~g} / \mathrm{saks}$ ile T0 konusundan elde edilirken, en düşük değer ise $195.95 \mathrm{~g} / \mathrm{saks}$ ile T5 konusunda elde edilmiştir. Parihar ve ark. (2015) tuz stresi bitkilerin verim ve verim bileşenlerinin önemli derecede azalmasına neden olduğunu ve toprak tuzluluğu arttıkça bitki verimi, yaprak gelişiminin azaldığını ve yapraklarda sararma miktarının arttığını ifade etmişlerdir.

Pessoa ve ark. (2019) yaptıkları çalışmalarında sulama suyu tuzluluğu $200 \mu \mathrm{S} \mathrm{cm}^{-1}$ ten $2000 \mu \mathrm{S} \mathrm{cm}^{-1}$ 'e kadar arttığında soğan bitkisinin verim ve verim 
bileşenlerinin önemli derecede azaldığını tespit

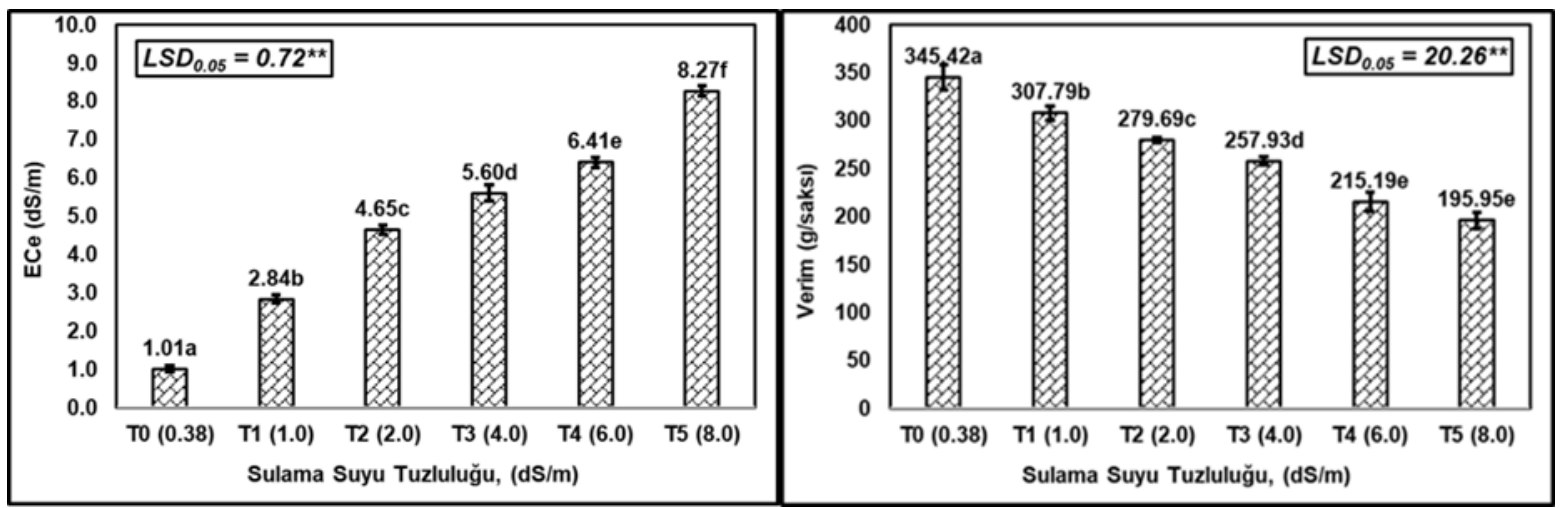

Şekil 1. Farklı sulama suyu tuzluluğuna göre toprak tuzluluğu (ECe) ve verim değerleri

Figure 1. Soil salinity and yield values according to different irrigation water salinity

\subsection{Yaprak mineral içerikleri ve oranları}

Farklı sulama suyu tuzluluğunun yaprak $\mathrm{Na}, \mathrm{K}, \mathrm{Ca}$ mineral içeriği ve $\mathrm{K} / \mathrm{Na}, \mathrm{Ca} / \mathrm{Na}, \mathrm{K} / \mathrm{Ca}$ oranları üzerine etkileri Şekil 2a-f'de gösterilmiştir.

\subsubsection{Yaprak $\mathrm{Na}^{+}$içeriği $(\mathrm{mg} / \mathrm{g})$}

Şekil 2a' da görüldüğü üzere, sulama suyu tuzluluğu arttıkça yaprak $\mathrm{Na}^{+}$içeriğinin arttığ tespit edilmiştir. En yüksek yaprak $\mathrm{Na}^{+}$içeriği $1.30 \mathrm{mg} / \mathrm{g}$ ile T5 konusundan elde edilirken en düşük değer ise $0.47 \mathrm{mg} / \mathrm{g}$ ile T0 konusundan elde edilmiştir. Elde edilen bulgular istatistiksel olarak incelendiğinde, T4 ve T5 konularının yaprak $\mathrm{Na}^{+}$içeriği arasında istatistiksel bir farklılık oluşmamıştır. Sulama suyu tuz içeriği $0.38 \mathrm{dSm}^{-1}$, den $8.0 \mathrm{dSm}^{-1}$ ye kadar arttığında yaprak $\mathrm{Na}^{+}$içeriğinin $\% 63.85$ oranında arttığı belirlenmiştir. Gözlenen bu durum sayesinde, yaprak $\mathrm{Na}^{+}$içeriğindeki artışın, sulama suyu tuzluluğundan kaynaklandığı söylenebilir. Tuz içeriği yüksek suların sulama da kullanılması sonucunda bitki kök bölgesinde tuz mineralleri artmasına neden olmaktadır (Arslan ve ark., 2018). Bitki kök bölgesinde aşırı $\mathrm{Na}^{+}$iyonunun birikmesi bitki gelişimini önemli derecede azaltmaktadır (Niu ve ark., 1995). Sulama suyu tuz içeriğinin artması toprak $\mathrm{Na}^{+}$ içeriğinin artmasını bununla birlikte yaprak $\mathrm{Na}^{+}$ içeriğinin artmasına neden olmaktadır (Qiu ve ark., 2018).

\subsubsection{Yaprak $\mathrm{K}^{+}$içeriği $(\mathrm{mg} / \mathrm{g})$}

Sulama suyu tuzluluğu arttıkça frenk soğanı bitkisinin yaprak $\mathrm{K}^{+}$içeriğinin azaldığı tespit edilmiştir. Konular arasında istatistiksel farklılık belirlenmiş ve en yüksek yaprak $\mathrm{K}^{+}$içeriğinin $\mathrm{T} 0$ konusundan tespit edilmiştir (Şekil 2b). T1, T2, T3, T4, T5 konularının yaprak $\mathrm{K}^{+}$içeriği değerleri T0 konusuna kiyasla sirasiyla \%18.0, \%31.4, \%37.2, \%40.7 ve \%48.8 oranında azaldığı tespit edilmiştir (Şekil b). Hatamnia ve ark. (2013), bitkide $\mathrm{K}^{+}$iyonunun, membran geçirgenliği, enzimatik tepkimeler, stomalarının açılıp/kapanması, anyon-katyon düzenlemesi, hücre büyümesi gibi çok önemli fizyolojik işlevleri olduğunu ifade etmişlerdir. Bitki sitoplazmasında yüksek $\mathrm{K}^{+}$ve düşük $\mathrm{Na}^{+}$bulunması, $\mathrm{K}^{+}$iyonunun enzimatik aktivitelerde etkin rol almasına neden olmaktadır (James ve ark., 2006). Tuz stresi bitkide iyon dengesizliğine neden olarak, bitkide dokularında aşırı $\mathrm{Na}^{+}$

iyonu birikmesine ve $\mathrm{K}^{+}$iyonu alımının azalmasına neden olmaktadır (Li ve ark., 2010). Çalışmadan elde edilen sonuçlar incelendiğinde, sulama suyu tuzluluğu arttıkça frenk soğanı bitkisinde $\mathrm{Na}^{+}$iyonu alımı artmış ancak $\mathrm{K}^{+}$iyonu alımı azalmıștır. Bitki kök bölgesinde çözünmüş tuz içeriğinin artması, toprağın ozmotik potansiyelinin artmasina neden olarak bu durumun ise toprakta $\mathrm{K}^{+}$iyonu hareketliliğinin azalmasına ve bitkinin $\mathrm{K}^{+}$alınabilirliğini azalmaktadır $(\mathrm{Hu}$ ve Schmidhalter, 2005).

Pessoa ve ark. (2019) yaptıkları çalışmada, sulama suyu tuz içeriği $200 \mu \mathrm{S} \mathrm{cm}{ }^{-1}$ 'ten $2000 \mu \mathrm{S} \mathrm{cm}^{-1}$ 'e kadar arttığında, soğan kök, yumru ve yapraklarında $\mathrm{K}^{+}$iyonu sirasiyla 30.97 - $28.11 \mathrm{gkg}^{-1}, 15.58$ - $11.82 \mathrm{gkg}^{-1}$, 25.38-21.23 $\mathrm{gkg}^{-1}$ arasında değişim gösterdiğini ve tuz stresi arttıkça $\mathrm{K}^{+}$iyonunun azaldığını tespit etmiş̧lerdir. Bitkide $\mathrm{K}^{+}$iyonu azalması ile ilgili benzer sonuçlar Babu ve ark. (2012) domates bitkisinde elde etmişlerdir.

\subsubsection{Yaprak $\mathrm{Ca}^{+2}$ içeriği $(\mathrm{mg} / \mathrm{g})$}

Şekil 2c'de görüldüğü üzere, sulama suyu tuzluluğu $0.38 \mathrm{dSm}^{-1}$ 'den $8.0 \mathrm{dSm}^{-1}$ 'e kadar arttıkça yaprak $\mathrm{Ca}^{+2}$ içeriği azalmaktadır. İstatistiksel olarak incelendiğinde, dört farklı grup oluşmuş ve en yüksek yaprak $\mathrm{Ca}^{+2}$ içeriği T0 konusunda belirlenmiştir. Ancak, T0 ve T1 konularının yaprak $\mathrm{Ca}^{+2}$ içerikleri arasında istatistiksel bir farklılık olmadığı tespit edilmiştir. Bununla birlikte, sulama suyu tuzluluğu $0.38 \mathrm{dSm}^{-1}$, den $8.0 \mathrm{dSm}^{-1}$ ye kadar arttığında frenk soğanı bitkisinin yaprak mineral 
içeriğinin \%30.93 oranında azaldığı belirlenmiştir. Ünlükara ve ark. (2008) sulama suyu tuzluluğunun marul bitkisinin yaprak $\mathrm{Ca}^{+2}$ içeriğini önemli derecede etkilediğini ve en düşük yaprak $\mathrm{Ca}^{+2}$ içeriğini $7.0 \mathrm{dSm}^{-1}$ ile sulanan bitkilerde belirlemişlerdir. Bir başka çalışmada Akça ve Samsunlu (2012), bitkide $\mathrm{Ca}^{+2}$ birikimi tuzluluk stresine bağlı olarak değişim gösterdiğini ve tuzluluk stresi arttıkça yaprakta $\mathrm{Ca}^{+2}$ iyonunun azaldığını tespit etmişlerdir.

\subsection{4. $\mathrm{K} / \mathrm{Na}, \mathrm{Ca} / \mathrm{Na}$ ve $\mathrm{K} / \mathrm{Ca}$ Oranlart}

Şekil 2d - 2f incelendiğinde, sulama suyu tuzluluğu arttıkça frenk soğanı bitkisinin yapraklarında $\mathrm{K}^{+} / \mathrm{Na}^{+}$, $\mathrm{Ca}^{+2} / \mathrm{Na}^{+}$ve $\mathrm{K}^{+} / \mathrm{Ca}^{+2}$ oranlarının azaldığ 1 tespit edilmiștir. En yüksek $\mathrm{K}^{+} / \mathrm{Na}^{+}, \mathrm{Ca}^{+2} / \mathrm{Na}^{+}$ve $\mathrm{K}^{+} / \mathrm{Ca}^{+2}$ oranı değerleri $0.38 \mathrm{dSm}^{-1}$ ile sulanan konuda elde edilirken en düşük değerler ise $8.0 \mathrm{dSm}^{-1}$ ile sulanan konudan elde edilmiştir.
Sulama suyu tuzluluğu $0.38 \mathrm{dSm}^{-1}$, den $8.0 \mathrm{dSm}^{-1}$ 'e kadar arttığında, frenk soğanı bitkisinin yaprak $\mathrm{K}^{+} / \mathrm{Na}^{+}$, $\mathrm{Ca}^{+2} / \mathrm{Na}^{+}$ve $\mathrm{K}^{+} / \mathrm{Ca}^{+2}$ oranları sirasiyla $\% 81.67, \% 75.34$ ve $\% 26.67$ oranında azaldığı tespit edilmiştir.

Elde edilen bulgulara göre, frenk soğanı bitkisinin yaprak $\mathrm{Na}^{+}$içeriği arttıkça, $\mathrm{K}^{+}$alınabilirliği $\mathrm{Ca}^{+2}$ göre daha çok azalmıştır.

Tuna ve ark. (2007) yaptıkları çalışmada, yüksek $\mathrm{NaCI}$ uygulamasında, domates bitkisinin dokularında $\mathrm{Na}^{+}$iyonunun arttığını ancak yaprak $\mathrm{Ca}^{+2}$ ve $\mathrm{K}^{+}$ içeriğinin azaldığını belirtmişlerdir. Singh ve ark. (2014) ise, yüksek tuzluluk koşullarında bitki dokularında yüksek $\mathrm{Na}^{+}$ve $\mathrm{CI}^{-}$iyonlarının bulunması, bitkilerde iyon dengesinin bozulmasina ve bunun sonucunda bitki dokularında yüksek düzeyde $\mathrm{Na}^{+} / \mathrm{Ca}^{+2}$ ve $\mathrm{Na}^{+} / \mathrm{K}^{+}$birikmesine neden olduğu ifade etmişlerdir.

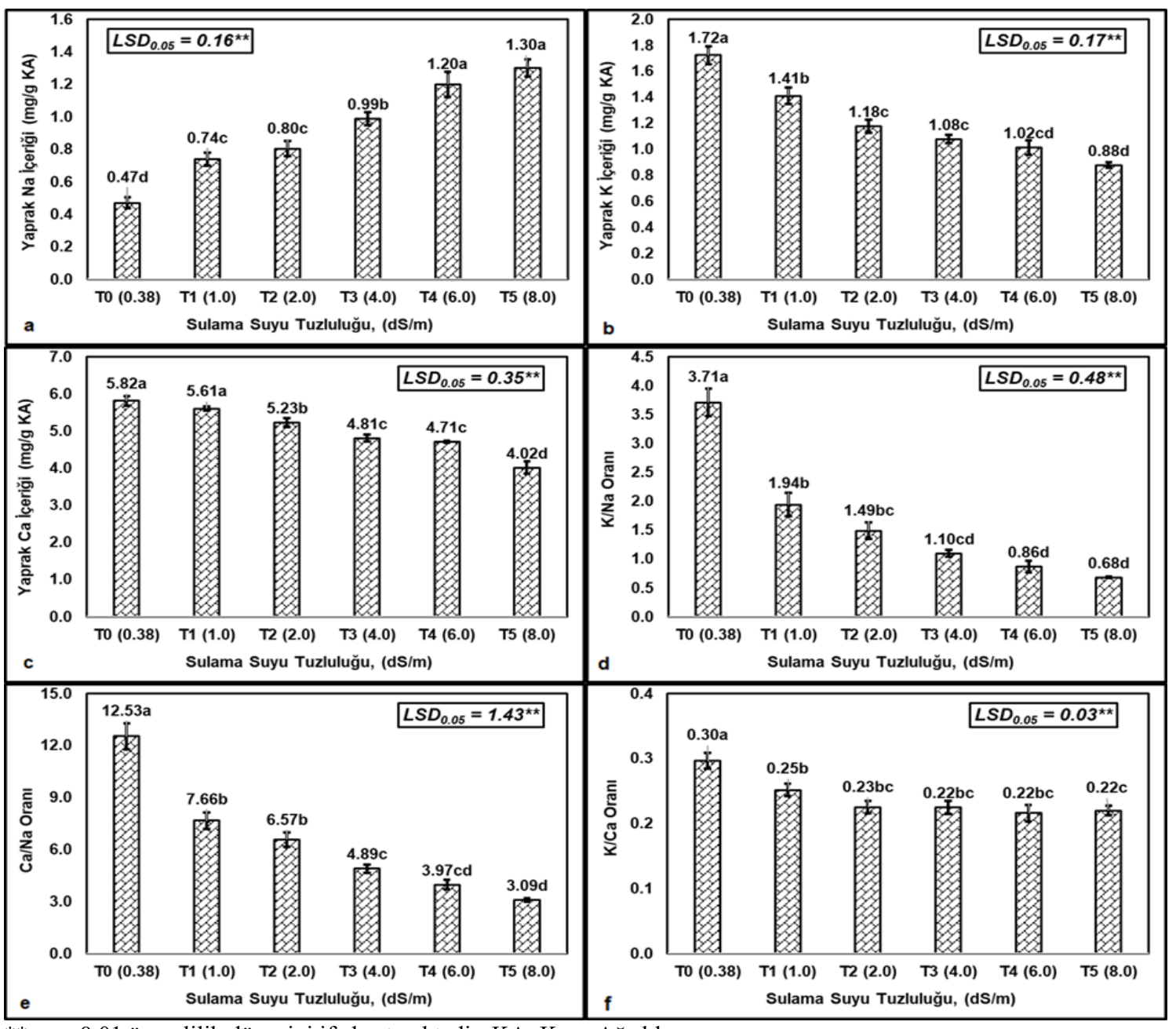

** $: \mathrm{p}<0.01$ önemlilik düzeyini ifade etmektedir. KA: Kuru Ağırlık

Şekil 2. Farklı sulama suyu tuzluluğunun frenk soğanı yaprak mineral içeriği üzerine etkileri Figure 2. Effects of irrigation water salinities on leaf mineral content of chives 
3.4. Oransal Verim ile $\mathrm{Na}^{+}, \mathrm{K}^{+}, \mathrm{Ca}^{+2}$ ve $\mathrm{K}^{+} / \mathrm{Na}^{+}$arasindaki ilişkiler

Şekil 3a'da görüldüğ̈̈ üzere, oransal verim ile yaprak mineral içerikleri ve $\mathrm{K}^{+} / \mathrm{Na}^{+}$orasındaki iliş̧i regresyon analizi ile incelenmiştir.

Oransal verim ile yaprak $\mathrm{Na}^{+}$içeriği arasındaki ilişki incelendiğinde, yaprak $\mathrm{Na}^{+}$içeriği arttıkça verim azalmaktadır. Bir başka ifade ile, regresyon eşitliği incelendiğinde, frenk soğanı bitkisinin yaprak $\mathrm{Na}^{+}$ içeriğindeki bir birimlik artış verim de oransal olarak \%44.4'lük bir azalmaya neden olduğu tespit edilmiştir. Arslan ve ark., (2018)'de frenk soğanı bitkisinin tuzluluk eşik değerini $1.13 \mathrm{dSm}^{-1}$ olarak belirlemişlerdir. Elde edilen bu değer, frenk soğanı bitkisinin tuzluluk stresine karşı hassas bitki olduğunu ifade etmişlerdir. $\mathrm{Bu}$ durum ise, frenk soğanı yetiştirildiği koşullarda bitki kök bölgesinde aşırı $\mathrm{Na}^{+}$ birikimi, bitki veriminin önemli derecede azalmasına neden olabileceği söylenebilir.

Oransal verim ile yaprak $\mathrm{K}^{+}$içeriği arasında pozitif bir ilişki olduğu tespit edilmiştir (Şekil 3b). Yaprak $\mathrm{K}^{+}$ içeriği arttıkça, frenk soğanı bitkisinin oransal veriminin arttığı belirlenmiştir. Regresyon eşitliği irdelendiğinde, frenk soğanı bitkisinin yaprak $\mathrm{K}^{+}$içeriğinde bir birimlik artış oransal verimde \%42.4'lük artış sağlamaktadır. Bu durum ise, frenk soğanı bitkisi için bitki kök bölgesinden $\mathrm{K}^{+}$iyonunun alınabilirliğinin yüksek olması verimi önemli derecede arttıracağı söylenebilir. Bir başka ifade ile, bitki besin elementlerinin bitki kökleri tarafından toprak çözeltisinden kolayca alınabilmesi için, toprak tuzluluğu göz önünde bulundurularak bitkinin tuzluluk eşik değerini geçmeyecek şekilde kontrol edilmesi gerektiği söylenebilir.

Oransal verim ile yaprak $\mathrm{Ca}^{+2}$ içeriği arasında pozitif bir ilişkinin olduğu tespit edilmiştir (Şekil 3c). Yaprak $\mathrm{Ca}^{+2}$ içeriği arttıkça frenk soğanı bitkisinin veriminin de $\operatorname{arttığ1~tespit~edilmiştir.~Oransal~verim~ve~yaprak~} \mathrm{Ca}^{+2}$ iyonu arasındaki regresyon ilişkisi incelendiğinde, yaprakta $\mathrm{Ca}^{+2}$ içeriğindeki bir birimlik artış oransal verimde \%19.2'lik artış sağladığı tespit edilmiştir. Frenk soğanı bitkisinin, oransal verimi ile yaprak $\mathrm{K}^{+} / \mathrm{Na}^{+}$oranı arasında pozitif bir ilişki olduğu tespit edilmiştir. Buna göre, yaprakta $\mathrm{K}^{+} / \mathrm{Na}^{+}$oranı arttıkça, oransal verim değerinin arttığ 1 belirlenmiştir. Bununla birlikte, yaprakta $\mathrm{K}^{+} / \mathrm{Na}^{+}$oranındaki bir birimlik artışın oransal verimde $\% 11.2^{\prime}$ lik artışa neden olduğu tespit edilmiștir. Bir başka ifade ile, yaprakta $\mathrm{Na}^{+}$birikmesi azaldıkça, $\mathrm{K}^{+} / \mathrm{Na}^{+}$oranının artacağını bununla birlikte transpirasyon düzeyinin artmasını sağlayarak bitkilerin tuz stresine karşı daha toleranslı olmasını ve bunun sonucunda ise, bitki gelişimi ve verimin artmasına katkı sağlayacağı söylenebilir.

Chen ve ark. (2016) tuz stresinin domates bitkisinin yaprak minerali üzerindeki etkisini inceledikleri çalışmada, yapraklarda $\mathrm{Na}^{+}$iyonu birikimi azaldıkça, $\mathrm{K}^{+}, \mathrm{Ca}^{+2}$ ve $\mathrm{K}^{+} / \mathrm{Na}^{+}$birikiminin arttığını ve bitkilerin daha iyi gelişim gösterdiğini belirtmişlerdir. Ashraf ve Ahmad (2000), genç fidelerin büyüme ve gelişimini sınırlandıran faktörlerin başında kök bölgesindeki NaCI birikiminden dolayı $\mathrm{K}^{+}, \mathrm{Ca}^{+2}$ gibi mutlak gerekli besin ihtiyaçlarını karşılayamadığını ifade etmişlerdir.

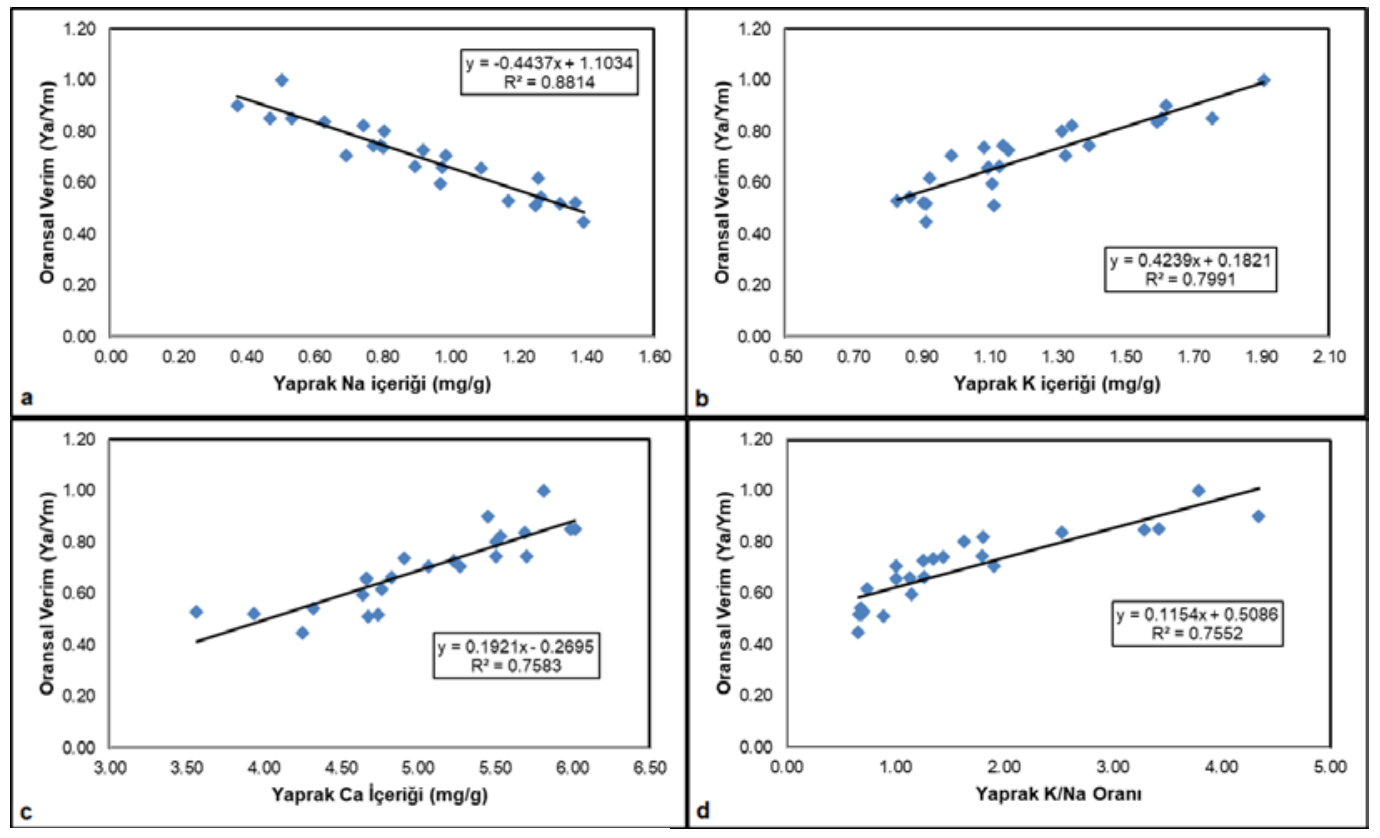

Şekil 3. Oransal verim ile yaprak $\mathrm{Na}^{+}, \mathrm{K}^{+}, \mathrm{Ca}^{+2}$ içeriği ve $\mathrm{K}^{+} / \mathrm{Na}^{+}$oranı arasındaki ilişkiler Figure 3. Relations between relative yield vs. leaf $\mathrm{Na}^{+}, \mathrm{K}^{+}, \mathrm{Ca}^{+2}$ content and $\mathrm{K}^{+} / \mathrm{Na}^{+}$rate 
Oransal verim ile yaprak $\mathrm{Na}^{+}, \mathrm{K}^{+}, \mathrm{Ca}^{+2}$ mineral içeriği ile $\mathrm{K}^{+} / \mathrm{Na}^{+}$oranı arasındaki regresyon ilişkisi irdelendiğinde, frenk soğanı bitkisinin oransal verimine en yüksek etkiye sahip iyonunun sirasıyla $\mathrm{Na}^{+}>\mathrm{K}^{+}>$ $\mathrm{Ca}^{+2}>\mathrm{K}^{+} / \mathrm{Na}^{+}$olduğu belirlenmiştir. Pessoa ve ark. (2019) yaptıkları çalışmada soğan bitkisini $200 \mu \mathrm{S} \mathrm{cm}^{-1}$ tuzlu su ile suladıklarında, soğan yumrusu kuru maddesinde biriken element düzeylerini sırasıyla $\mathrm{K}^{+}>$ $\mathrm{Ca}^{+2}>\mathrm{CI}^{-}>\mathrm{Mg}^{+2}>\mathrm{Na}^{+}$olarak vermişlerdir. Korkmaz ve ark. (2016)' da tuz stresi koşullarında bitkilerde mineral birikiminin, bitki çeşidine, uygulanan tuz çeşidi ve miktarına, yetiştirme koşullarına ve bitkinin tuz stresine maruz kalma süresine bağlı olarak değişim gösterebileceğini ifade etmişlerdir. Ayrıca, Cerda ve ark. (1995), tuz stresinin bitki gelişimi üzerindeki iyonik dengesizliğin oluşmasındaki en önemli sebep olarak bitkide oluşan $\mathrm{Ca}^{+2}$ ve $\mathrm{K}^{+}$iyon dengesizliğinden kaynaklandığını saptamışlardır. Hong ve ark. (2009) ise, bitkide $\mathrm{Na}^{+}$içeriğinin artması $\mathrm{K}^{+}$alınımının engellenmesine neden olduğunu tespit etmişlerdir. Çalı̧̧mamızdan elde edilen bulgular göz önünde bulundurulduğunda, $\mathrm{Na}^{+}, \mathrm{K}^{+}, \mathrm{Ca}^{+2}$ iyonları ile $\mathrm{K}^{+} / \mathrm{Na}^{+}$ oranı parametreleri ile oransal verim arasında yüksek $\mathrm{R}^{2}$ değerlerine sahip olması; bu parametrelerin frenk soğanı bitkisinin tuza karşı toleransının belirlenmesinde kullanılabileceğini göstermiştir.

\subsection{Parametreler arasındaki ilişkiler}

Farklı sulama suyu tuzluluğu koşullarında yetiştirilen frenk soğanı bitkisinin yaprak mineralleri, yaprak mineral oranları, verim, bitki su tüketimi ve toprak tuzluluğu arasındaki korelasyon analizi Şekil 4'te gösterilmiștir. İncelenen tüm parametreler arasındaki ilişkiler pearson korelasyon analizine göre $\mathrm{p}<0.01$ düzeyine göre önemli olduğu tespit edilmiştir.

Yaprak $\mathrm{K}^{+}, \mathrm{Ca}^{+2}$ içerikleri, yaprak $\mathrm{K}^{+} / \mathrm{Na}^{+}, \mathrm{Ca}^{+2} / \mathrm{Na}^{+}$, $\mathrm{K}^{+} / \mathrm{Ca}^{+2}$, verim, bitki su tüketimi parametreleri ile yaprak $\mathrm{Na}^{+}$içeriği ve toprak tuzluluğu (EC) arasında negatif yönlü ilişki belirlenmiştir. Buna göre, toprak tuzluluğu ile yaprakta $\mathrm{Na}^{+}$içeriğinin artması bitki besin elementlerinin alımını ve yaprak mineral oranlarını önemli derecede olumsuz etkilediği söylenebilir. ET, $\mathrm{K}^{+}, \mathrm{Ca}^{+2}, \mathrm{~K}^{+} / \mathrm{Na}^{+}, \mathrm{Ca}^{+2} / \mathrm{Na}^{+}, \mathrm{K}^{+} / \mathrm{Ca}^{+2}$ parametrelerinin artması frenk soğanı bitkisinin verimini olumlu yönde etkilediği belirlenmiş̧ir. Bitki su tüketimi ile verim, $\mathrm{K}^{+}$, $\mathrm{Ca}^{+2}, \mathrm{~K}^{+} / \mathrm{Na}^{+}, \mathrm{Ca}^{+2} / \mathrm{Na}^{+}, \mathrm{K}^{+} / \mathrm{Ca}^{+2}$ parametreleri arasinda pozitif yönlü bir ilişkilerin olduğu tespit edilmiştir. Buna göre, bitki su tüketimi arttıkça yaprak $\mathrm{K}^{+}, \mathrm{Ca}^{+2}$, $\mathrm{K}^{+} / \mathrm{Na}^{+}, \mathrm{Ca}^{+2} / \mathrm{Na}^{+}, \mathrm{K}^{+} / \mathrm{Ca}^{+2}$ içeriğıi değerlerinin arttı̆̆ saptanmıştır.

Yaprak $\mathrm{K}^{+}$içeriği ile $\mathrm{EC}$ ve yaprak $\mathrm{Na}^{+}$içeriği arasında negatif yönlü bir ilişki olduğu tespit edilmiş, buna göre yaprak $\mathrm{K}^{+}$içeriği arttıkça $\mathrm{EC}$ ve yaprak $\mathrm{Na}^{+}$ içeriğinde azalış meydana geldiği belirlenmiştir. Yaprak $\mathrm{K}^{+}$içeriği ile verim, ET, $\mathrm{Ca}^{+2}, \mathrm{~K}^{+} / \mathrm{Na}^{+}, \mathrm{Ca}^{+2} / \mathrm{Na}^{+}$, $\mathrm{K}^{+} / \mathrm{Ca}^{+2}$ parametreleri arasında pozitif yönlü bir ilişki olduğu saptanmıştır. Yaprak $\mathrm{K}^{+} / \mathrm{Na}^{+}, \mathrm{Ca}^{+2} / \mathrm{Na}^{+}, \mathrm{K}^{+} / \mathrm{Ca}^{+2}$ parametreleri ile verim, bitki su tüketimi, $\mathrm{K}^{+}, \mathrm{Ca}^{+2}$ parametreleri arasında pozitif yönlü bir ilişki bulunmuştur. Buna göre, yaprakta $\mathrm{K}^{+} / \mathrm{Na}^{+}, \mathrm{Ca}^{+2} / \mathrm{Na}^{+}$ oranları arttıkça verim ve bitki su tüketimi değerlerinin

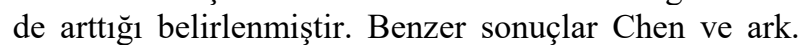
(2016), domates bitkisi yaprak $\mathrm{Na}^{+}$içeriği ve $\mathrm{K}^{+} / \mathrm{Na}^{+}$ oranının bitki su tüketimi ve verim parametreleri arasında negatif ilişkinin olduğunu, ancak yaprak $\mathrm{K}^{+}$ve $\mathrm{Ca}^{+2}$ içeriğinin bitki su tüketimi ve verim arasında pozitif ilişki olduğunu ifade etmişlerdir.

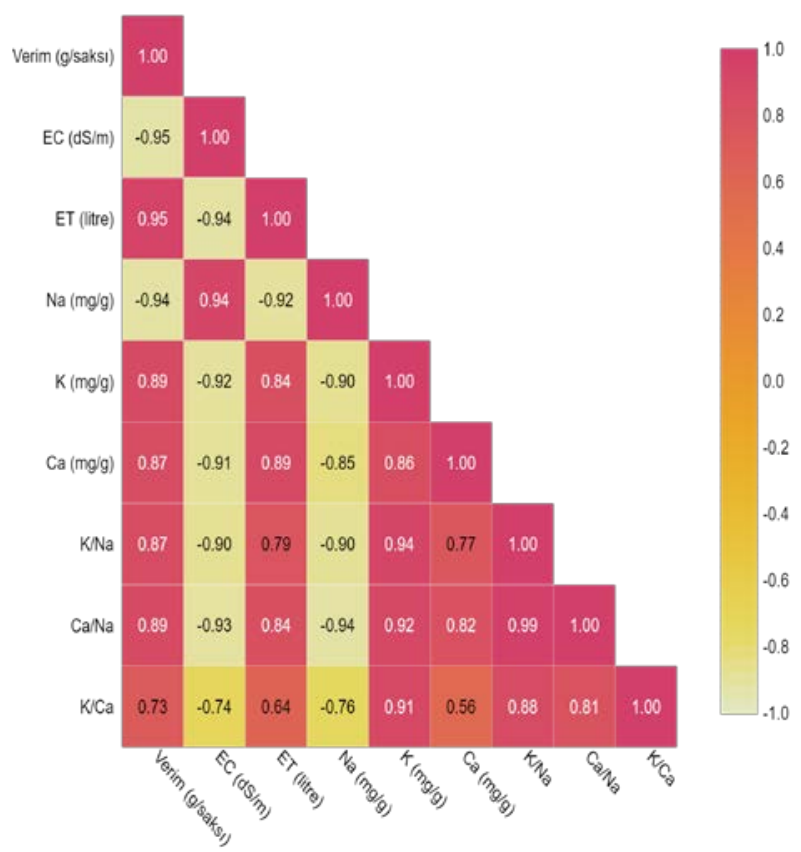

\#: Pearson korelasyon analizine göre, tüm ikili ilişkiler arasında $\mathrm{p}<0.01$ önemlilik düzeyinde ilişki bulunmaktadır.

Şekil 4. İncelenen parametreler arasındaki korelasyon matrisi

Figure 4. Correlation matrix between examined parameters

3.6. Yaprak $\mathrm{Na}^{+}, \mathrm{K}^{+}, \mathrm{Ca}^{2+}$ içeriği ve yaprak $\mathrm{K}^{+} / \mathrm{Na}^{+}$ oranı parametrelerinin sulama suyu tuzluluğu ve toprak tuzluluğu arasindaki regresyon denklemleri ve tepki yüzey grafikleri ile gösterilmesi

Sulama suyu tuzluluğu (ECiw) ve toprak tuzluluğunun (ECe) yaprak mineral içeriği üzerine etkileri tepki yüzey metodolojisi ile modellenmesine ilişkin kuadratik regresyon eşitlikleri, yüzey tepki grafikleri Şekil 5' te gösterilmiştir. Modellerin varyans analiz sonuçları Çizelge 3'te gösterilmiştir.

Şekil 5a'da yaprak $\mathrm{Na}^{+}$içeriğinin sulama suyu tuzluluğu ve toprak tuzluluğu değiş̧kenleri ile oluşturulan kuadratik regresyon denklemi ile tahmin edilmesi gösterilmiştir. Elde edilen modelin, istatistiksel olarak $\mathrm{p}<0.001$ düzeyinde önemli olduğu tespit edilmiş ve yaprak $\mathrm{Na}^{+}$içeriğginin $\left(\mathrm{R}^{2}=0.89\right)$ \%89'unu regresyon eşitliği ile tahmin edilebileceğini göstermiştir. Tepki 
yüzey grafiği incelendiğinde, sulama suyu tuzluluğu ve toprak tuzluluğu arttıkça yaprak $\mathrm{Na}^{+}$içeriğinin arttığ saptanmıştır. Ancak, sulama suyu tuzluluğu ve toprak tuzluluğundaki bir birimlik artış yaprak $\mathrm{Na}^{+}$içeriğini sirasıyla 0.095 ve 0.072 miktar artışa neden olduğu belirlenmiştir. Buna göre, sulama suyu tuz içeriğinin toprak tuzluluğuna göre yaprakta $\mathrm{Na}^{+}$birikimi üzerine daha etkili olduğu söylenebilir. Frenk soğanı bitkilerinde en düşük yaprak $\mathrm{Na}^{+}$içeriğgi, sulama suyu tuzluluğunun $0.44 \mathrm{dSm}^{-1}$ ve toprak tuzluluğunun 0.82 $\mathrm{dSm}^{-1}$ olduğu koşullarda bulunmuştur (Çizelge 2).

$\mathrm{Bu}$ durum ise, frenk soğanı bitkisi için sulama suyu tuzluluğu ve toprak tuzluluğu eşik değerlerinin 0.44 ve $0.82 \mathrm{dSm}^{-1}$ olduğunu ifade etmektedir. Özellikle, toprakta $0.82 \mathrm{dSm}^{-1}$ 'den daha fazla tuz birikmesi frenk soğanı bitkisinin mutlak besin minerallerinin alınabilirliğini önemli derecede azaltacağını ifade etmektedir.
Şekil $5 b$ irdelendiğinde, yaprak $\mathrm{K}^{+}$içeriğinin sulama suyu tuzluluğu ve toprak tuzluluğu arasında parabolik bir ilişki olduğu tespit edilmiştir. Sulama suyu tuzluluğu ve toprak tuzluluğu arttıkça, yaprak $\mathrm{K}^{+}$içeriği değerleri azalmıştır (Şekil 5b). Ancak, sulama suyunun tuz içeriği arttıkça, yaprak $\mathrm{K}^{+}$içeriği hafif azalış gerçekleşmektedir, toprak tuzluluğuna göre ise $5.4 \mathrm{dSm}^{-}$ 1 , e kadar yaprak $\mathrm{K}^{+}$içeriği keskin bir şekilde azalmış ve bu değerden sonra ise hafif bir şekilde azaldığ belirlenmiştir. Sulama suyu tuzluluğu ve toprak tuzluluğu değişkenlerinin regresyon katsayıları sırasıyla -0.010 ve -0.271 tespit edilmiştir. Elde edilen bu durum, toprak tuzluluğundaki bir birimlik artış sulama suyu tuzluluğuna göre yaprak $\mathrm{K}^{+}$içeriğini $\% 96.3$ oranında daha fazla azalmasına neden olacağını ifade etmektedir. Matematiksel modele göre, en yüksek yaprak $\mathrm{K}^{+}$içeriği değeri için sulama suyu tuzluluğu ve toprak tuzluluğu değerleri sırasiyla $0.57 \mathrm{dSm}^{-1}$ ve $0.82 \mathrm{dSm}^{-1}$ olduğu tespit edilmiştir.

Çizelge 1. Yaprak $\mathrm{Na}^{+}, \mathrm{K}^{+}, \mathrm{Ca}^{+2}$ ve $\mathrm{K}^{+} / \mathrm{Na}^{+}$oranı parametrelerinin matematiksel modeller ile tahmin edilmesi

Table 1. Estimation of leaf $\mathrm{Na}^{+}, \mathrm{K}^{+}, \mathrm{Ca}^{+2}$ and $\mathrm{K}^{+} / \mathrm{Na}^{+}$ratio parameters with mathematical models

Regresyon Denklemleri

$\mathrm{Na}(\mathrm{mg} / \mathrm{g})=0.312+0.095 * \mathrm{ECiw}+0.072 * \mathrm{ECe}-0.004 * \mathrm{ECiw}^{*} \mathrm{ECe}-0.001 *$ ECiw2

$\mathrm{K}(\mathrm{mg} / \mathrm{g})=2.128-0.010 * \mathrm{ECiw}-0.271 * \mathrm{ECe}-0.003 * \mathrm{ECiw}^{2}+0.018 * \mathrm{ECe}^{2}$

$\mathrm{Ca}(\mathrm{mg} / \mathrm{g})=6.00-0.49 * \mathrm{ECiw}+0.082 * \mathrm{ECiw}^{2}-0.005 * \mathrm{ECiw}^{2} * \mathrm{ECe}$

$\mathrm{K} / \mathrm{Na}$ Oran $1=4.808-1.522 * \mathrm{ECe}+0.185 * \mathrm{ECe}^{2}-0.007 * \mathrm{ECiw}^{*} \mathrm{ECe}^{2}$

ECiw : Sulama suyu tuzluluğu; ECe: Toprak tuzluluğu'nu ifade etmektedir.

Çizelge 2. $\mathrm{Na}^{+}, \mathrm{K}^{+}, \mathrm{Ca}^{+2}, \mathrm{~K}^{+} / \mathrm{Na}^{+}$parametreleri için optimum toprak ve sulama suyu tuzluluğu koşulları

Table 2. Optimum soil and irrigation water salinity conditions for $\mathrm{Na}^{+}, \mathrm{K}^{+}, \mathrm{Ca}^{+2}, \mathrm{~K}^{+} / \mathrm{Na}^{+}$parameters

\begin{tabular}{lllll}
\hline Parametreler & $\begin{array}{l}\text { Değer } \\
(\mathrm{mg} / \mathrm{g})\end{array}$ & $\begin{array}{l}\text { Sulama suyu } \\
\text { tuzluluğu }\left(\mathrm{dSm}^{-1}\right)\end{array}$ & $\begin{array}{c}\text { Toprak tuzluluğu } \\
\left(\mathrm{dSm}^{-1}\right)\end{array}$ \\
\hline Yaprak $\mathrm{Na}^{+}$içeriği & En düşük & 0.41 & 0.44 & 0.82 \\
\hline Yaprak K ${ }^{+}$içeriği & En yüksek & 1.51 & 0.57 & 0.82 \\
\hline Yaprak Ca $\mathrm{Ca}^{+}$içeriği & En yüksek & 5.85 & 0.41 & 0.80 \\
\hline $\mathrm{K}^{+} / \mathrm{Na}^{+}$oranı & En yüksek & 3.69 & 0.49 & 0.81 \\
\hline
\end{tabular}

Sulama suyu tuzluluğu ve toprak tuzluluğu değişkenlerinin yaprak $\mathrm{Ca}^{2+}$ içeriği ve yaprak $\mathrm{K}^{+} / \mathrm{Na}^{++}$ oranı üzerine etkileri Şekil $5 \mathrm{c}$ ve Şekil $5 \mathrm{~d}^{\prime} \mathrm{de}$ gösterilmiştir. En yüksek yaprak $\mathrm{Ca}^{+2}$ içeriği $0.41 \mathrm{dSm}^{-1}$ sulama suyu tuzluluğu ve $0.80 \mathrm{dSm}^{-1}$ toprak tuzluluğunun olduğu koşullarda belirlenmiştir. Çalışmada elde edilen bulgulara göre, sulama suyunun tuz içeriği arttıkça bitki kök bölgesinde aşırı $\mathrm{Na}^{+}$iyonu birikmesi, bitkide $\mathrm{Na}^{+}$alımının arttırmış ve buna bağlı olarak ise $\mathrm{Ca}^{+2}$ ve yaprak $\mathrm{K}^{+} / \mathrm{Na}^{+}$oranının azalmasına neden olmuştur. Tuz stresi koşullarında bitkilerde görülen en belirgin özelliklerden biri bitkilerde iyon dengesizliğine neden olmasıdır. $\mathrm{Bu}$ iyon dengesizliğinin nedeni ise, Fageria (2001), $\mathrm{Na}^{+}$ve diğer iyonlar arasındaki antagonizmden kaynaklandığını ifade etmiştir. Ayrıca, yapraklarda tuz stresi arttıkça, yaprak $\mathrm{Ca}^{+2}$ içeriğgi ve $\mathrm{K}^{+} / \mathrm{Na}^{+}$oranının azalması bitkilerin tuzluluk eşik değerine bağlı olarak değişim gösterebileceği söylenebilir. Çünkü, bitkilerin tuz stresine karşı toleransı az olan bitkiler için toprak tuz içeriği arttıkça kökleri ile toprak çözeltisinden $\mathrm{Ca}^{+2}$ ve $\mathrm{K}^{+}$iyonlarını alımı azalacağı söylenebilir. Al-Karaki (2000) yaptı̆̆ 1 çalı̧̧mada, domates bitkisinde yüksek düzeyde $\mathrm{Na}^{+}, \mathrm{K}^{+} / \mathrm{Na}^{+}$ve $\mathrm{Ca}^{+2} / \mathrm{Na}^{+}$oranlarının bulunması 
domates bitkisinin tuz stresine karşı toleransı arttırdığını belirtmiştir. Regresyon analiz sonuçlarına göre, yaprak $\mathrm{Ca}^{+2}$ içeriği ve yaprak $\mathrm{K}^{+} / \mathrm{Na}^{+}$oranı modellerinin çoklu belirleme katsayısı $\left(\mathrm{R}^{2}\right)$ sirasiyla 0.90 ve 0.93 olarak belirlenmiştir. Yüksek $R^{2}$ değeri $\left(R^{2}>0.80\right)$, çalışmadan elde edilen verilerin ikinci dereceden polinom denklemleri ile iyi bir sonuç gösterdiğini ifade etmektedir (Leardi, 2009). Elde edilen bulgulara göre, yüzey tepki metodolojisi kullanılarak frenk soğanı bitkisinin yaprak mineral içeriği yüksek düzeyde gerçeğe yakın değerlerinin tahmin edilebileceğini göstermiştir.
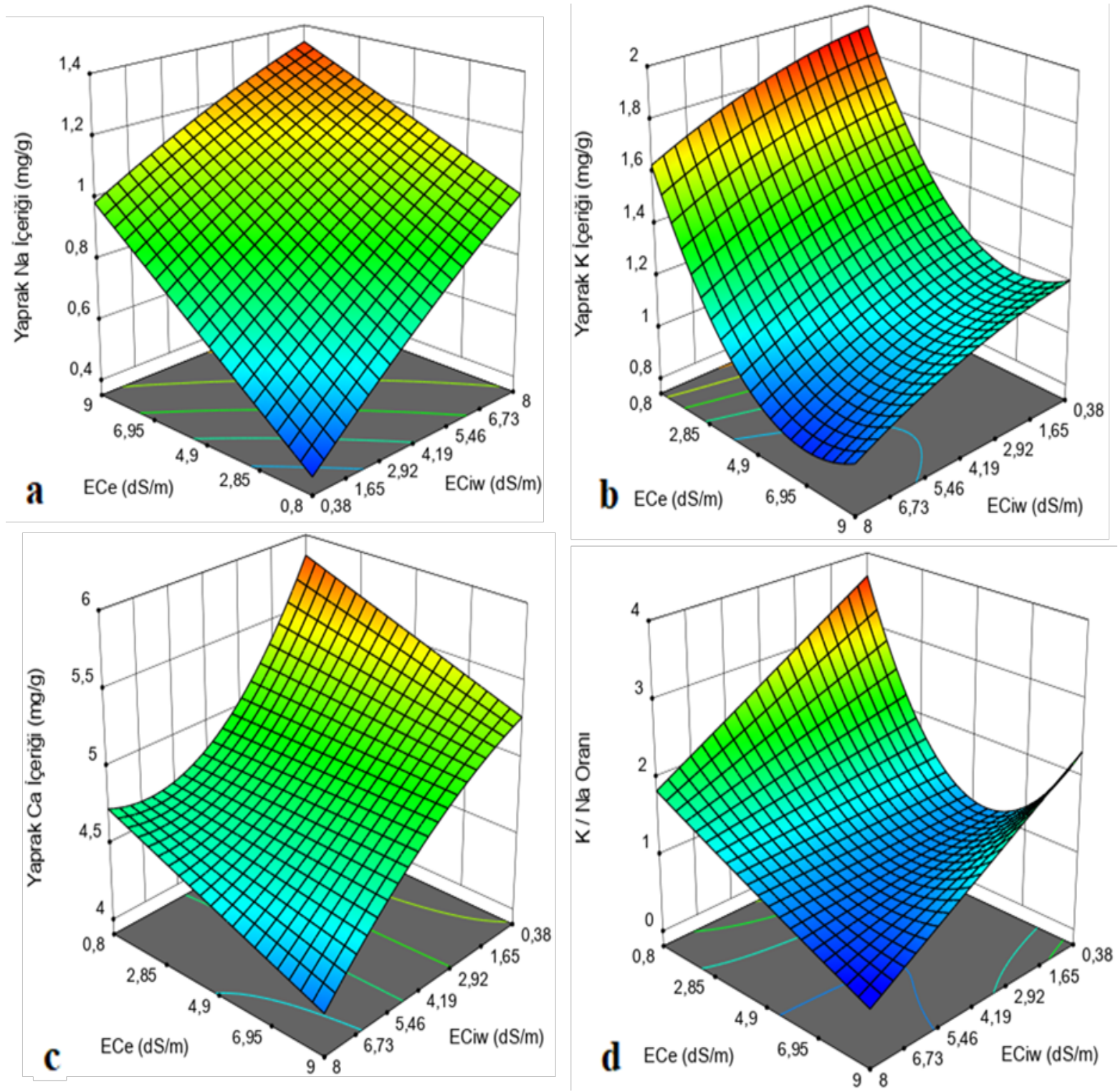

Şekil 5. Sulama suyu tuzluluğu ve toprak tuzluluğunun yaprak mineral içerikleri ile ilişkileri ve yüzey tepki grafikleri ile gösterilmesi (a: Yaprak $\mathrm{Na}^{+}$içeriği, b: Yaprak K${ }^{+}$içeriği, c: Yaprak $\mathrm{Ca}^{+2}$ içeriği, d: $\mathrm{Yaprak} \mathrm{K}^{+} / \mathrm{Na}^{+2}$ oranı, ECiw : Sulama suyu tuzluluğu; ECe: Toprak tuzluluğu).

Figure 5. Relations among irrigation water salinity and soil salinity with leaf mineral contents and showing with response surface graphs (a: Leaf $\mathrm{Na}^{+}$content, b: Leaf $\mathrm{K}^{+}$content, c: Leaf $\mathrm{Ca}^{+2}$ content, d: Leaf $\mathrm{K}^{+} / \mathrm{Na}^{+2}$ ratio, ECiw : Irrigation water salinity; ECe: Soil salinity). 
Çizelge 3. Yaprak mineral içerikleri için kuadratik tepki yüzey modellerinin ANOVA sonuçları Table 3. ANOVA results of quadratic response surface models for leaf mineral contents

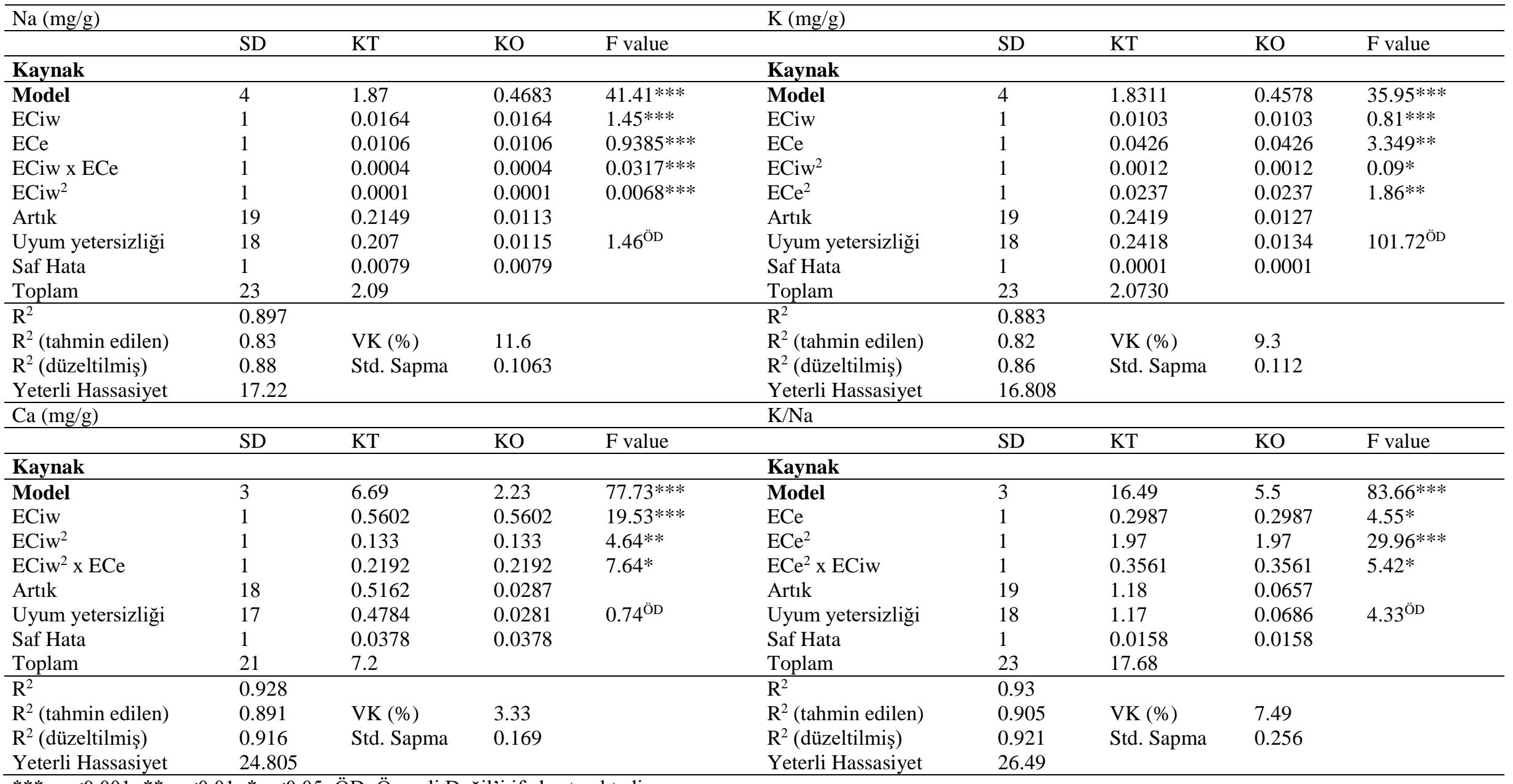

***: $\mathrm{p}<0.001 ;{ }^{* *}: \mathrm{p}<0.01 ; *: \mathrm{p}<0.05$; ÖD: Önemli Değil'i ifade etmektedir. 


\section{Sonuç}

$\mathrm{Bu}$ çalışmada, farklı sulama suyu tuzluluğunun frenk soğanı bitkisinin yaprak mineral içeriği üzerine etkileri incelenmiştir. Elde edilen sonuçlar incelendiğinde, en yüksek yaprak mineral içeriği değerleri $0.38 \mathrm{dSm}^{-1}$ konusunda, en düşük değerler ise $8.0 \mathrm{dSm}^{-1}$ konusunda tespit edilmiştir. Ayrıca, toprak tuzluluğu arttıkça, frenk soğanı bitkisinin topraktan $\mathrm{K}^{+}$ve $\mathrm{Ca}^{2+}$ alımını önemli derecede azalttığ 1 tespit edilmiştir. Bununla birlikte, $\mathrm{Na}^{+}, \mathrm{K}^{+}, \mathrm{Ca}^{+2}$ mineral içeriği ve $\mathrm{K}^{+} / \mathrm{Na}^{+}$oranı parametreleri ile oransal verim arasında yüksek $\mathrm{R}^{2}$ değerlerine sahip olması, frenk soğanı bitkisinin tuza karşı toleransının belirlenmesinde yaprak $\mathrm{Na}^{+}, \mathrm{K}^{+}, \mathrm{Ca}^{+2}$ mineral içeriği ve $\mathrm{K}^{+} / \mathrm{Na}^{+}$oranı parametrelerinin kullanılabileceği saptanmıştır.

Tuzlu suların bitki yetiştiriciliğinde kullanıldığında, bitki veriminin yanı sıra bitkilerin mineral içeriği ve kalitesi de göz önünde bulundurulmalıdır. Bu nedenle, frenk soğanı bitkisi için optimum yaprak mineral içeriklerinin elde edilebilmesi için toprak tuzluluğu için $0.81 \mathrm{dSm}^{-1}$ ve sulama suyu tuzluluğu için $0.48 \mathrm{dSm}^{-1}$ olduğu koşullarda tespit edilmiştir. Bu duruma dikkat edilerek, frenk soğanı bitkisinin tuzluluk eşik değeri tespit edilerek, bitki kök bölgesinde aşırı tuz birikimini önlemek amaciyla sulama suyu ile birlikte yıkama suyunun verilmesi önerilebilir. Yüzey tepki modelleri kullanılarak, bitkilerin yaprak mineral içeriğinin bitki su tüketimi ve toprak tuzluluğu parametreleri ile tespit edilmesinin mümkün olduğu saptanmıştır. Bununla birlikte, ölçülen ve tahmin edilen değerler arasında yüksek ilişki olması elde edilen modellerin yeterli tahmin sağladığını ve modellerin uygulanabilirliğini göstermiştir. Bu durum göz önünde bulundurulduğunda, yüksek verim ve kaliteli ürün elde edilmesinde, optimum koşulların belirlenmesi amacıyla yüzey tepki modellerinin kullanılması sürdürülebilir tarım açısından önemli katkılar sağlayacaktır.

\section{Kaynaklar}

Akça, Y., Samsunlu, E., 2012. The effect of salt stress on growth, chlorophyll content, proline and nutrient accumulation, and K/Na ratio in walnut. Pak. J. Bot, 44(5): 1513-1520.

Al-Harbi, A. R., Hegazi, H. H., Alsadon, A. A., ElAdgham, F., 2002. Growth and yield of onion (Allium cepa L.) Cultivars under different levels of irrigation water salinity. Journal of King Saud University, 14(1): 23-32.

Al-Karaki, G.N., 2000. Growth, water use efficiency and sodium and potassium acquisition by tomato cultivars grown under salt stres. Journal of Plant Nutrition, 23: 1-8.

Amjad, M., Akhtar, S. S., Yang, A., Akhtar, J., Jacobsen, S. E., 2015. Antioxidative response of quinoa exposed to iso-osmotic, ionic and non-ionic salt stress. Journal of Agronomy And Crop Science, 201(6): 452-460.

Arslan, H., Kiremit, M. S., Güngör, A., 2018. Impacts of different water salinity levels on salt tolerance, water use, yield, and growth of chives (Allium schoenoprasum). Communications in Soil Science and Plant Analysis, 49(20): 2614-2625.

Ashraf, M., Ahmad, S., 2000. Influence of sodium chloride on ion accumulation, yield components and fibre characteristics in salt-tolerant and salt sensitive lines of cotton (Gossypium hirsutum L.) Fields Crops Res. 66, 115-127.

Ayers, R. S., ve Westcot, D. W., 1985. Water quality for agriculture. FAO Irrigation and drainage paper 29 Rev. 1. Food and Agricultural Organization. Rome, $1,74$.

Babu, M. A., Singh, D., Gothandam, K. M., 2012. The effect of salinity on growth, hormones and mineral elements in leaf and fruit of tomato cultivar PKM1. J Anim Plant Sci, 22(1): 159-164.

Cerda, A., Pardines, J., Botella, M.A., Martinez, V., 1995. Osmotic sensitivity in relation to salt sensitivity in germination of barleyseeds. Plant Cell Environ., 9: 721- 725.

Collins, C.A. and Seeney F.M., 1999. Statistical Experiment Design and Interpretation: An Introduction with Agricultural Examples, Wiley, Chichester.

FAO. 2018 . Food and Agriculture Organization. http://www.fao.org/soils-portal/soilmanagement/management-of some-problemsoils/salt-affected-soils/more-information-on-saltaffected-soils/en/

(Erişim tarihi: 10.05.2020).

Fageria, V.D., 2001. Nutrient interactions in crop plants. J. of Plant Nutrition, 24(8): 1269-1290.

Gill, S. S., Tuteja N., 2010. Reactive oxygen species and antioxidant machinery in abiotic stress tolerance in crop plants. Plant Physiology and Biochemistry, 48 (12):909-30. doi: 10.1016/j.plaphy.2010.08.016.

Grattan, S. R.,Grieve, C. M., 1998. Salinity-mineral nutrient relations in horticultural crops. Scientia horticulturae, 78(1-4), 127-157.

Hatamnia, A.A., Abbaspour, N., Darvishzadeh, R., Rahmani F., ve Heidari, R.,2013. Effect of salt stress on growth, ion content and photosynthesis of two oriental tobacco (Nicotiana tabacum) cultivars. Intl. J. Agr. Crop Sci. 6:757-761.

Hong, C.Y., Chao, Y.Y., Yang, M.Y., Cho, S.C., Kao, C.H., 2009. $\mathrm{Na}^{+}$but not $\mathrm{Cl}^{-}$or osmotic stress is involved in $\mathrm{NaCl}$ induced expression of glutathione reductase in roots of rice seedlings. Journal of Plant Physiology, 166: 1598-1606.

Hu, Y., ve Schmidhalter, U., 2005. Drought and salinity: a comparison of their effects on mineral 
nutrition of plants. Journal of Plant Nutrition and Soil Science, 168(4): 541-549.

James, R.A., Munns, R., Von Caemmerer, S., Trejo, C., Miller, C., ve Condon, T. A., 2006. Photosynthetic capacity is related to the cellular and subcellular partitioning of $\mathrm{Na}^{+}, \mathrm{K}{ }^{+}$and $\mathrm{Cl}^{-}$in salt-affected barley and durum wheat. Plant Cell Environ. 29:2185-2197.

Kacar, B., İnal, A., 2010. Bitki analizleri (2. Baskı). Nobel Yayın Dağıtım, Ankara.

Keller, J., Bliesner, R.D., 1990. Sprinkle and Trickle Irrigation. Blackburn Press, New Jersey, USA.

Korkmaz, A., Karagöl, A., Horuz, A., 2016. Katı ortam kültüründe NaCI'ün domates bitkisinin verim ve meyve kalitesi üzerine etkileri. Anadolu Tarım Bilimleri Dergisi, 31(1): 127-135.

Leardi, R., 2009. Experimental design in chemistry: a tutorial. Anal. Chim. Acta 652, 161-172. https://doi.org/10.1016/j.aca.2009.06.015.

Li, R., Shi, F., Fukuda, K., Yang, Y., 2010. Effects of salt and alkali stresses on germination, growth, photosynthesis and ion accumulation in alfalfa (Medicago sativa L.). Soil Science and Plant Nutrition, 56(5), 725-733.

Luo, M. B., ve Liu, F., 2011. Salinity-induced oxidative stress and regulation of antioxidant defense system in the marine macroalga Ulva Prolifer. Journal of Experimental Marine Biology and Ecology 409 (12):223-8. doi: 10.1016/j.jembe.2011.08.023.

Montgomery, D. C., 2008. Design and Analysis of Experiments .John Wiley and Sons, New York, NY.

Myers, R.H., Montgomery, D.C., 2002. Response surface methodolgy process and product optimization using designed experiments, John Wiley\& Sons, Inc.,Newyork

Niu, X., Bressan, R. A., Hasegawa, P. M., Pardo, J. M., 1995. Ion homeostasis in $\mathrm{NaCl}$ stress environments. Plant physiology, 109(3): 735.

Parihar, P., Singh, S., Singh, R., Singh, V. P., Prasad, S. M., 2015. Effect of salinity stress on plants and its tolerance strategies: a review. Environmental Science and Pollution Research, 22(6): 4056-4075.

Pilkington, J.L., Preston, C., Gomes, R.L., 2014. Comparison of response surface methodology (RSM) and artificial neural networks (ANN) towards efficient extraction of artemisinin from Artemisia annua. Ind. Crops Prod. 58: 15-24. https://doi.org/10. 1016/j.indcrop.2014.03.016.

Pessoa, L. G. M., dos Santos Freire, M. B. G., dos Santos, R. L., Freire, F. J., Miranda, M. F. A., dos Santos, P. R. 2019. Saline water irrigation in semiarid region: I-effects on soil chemical properties. Australian Journal of Crop Science, 13(7): 1169.

Sassine, Y. N., Alturki, S. M., Germanos, M., Shaban, N., Sattar, M. N., Sajyan, T. K., 2020. Mitigation of salt stress on tomato crop by using foliar spraying or fertigation of various products. Journal of Plant Nutrition, 1-15.

Searchinger, T., Waite, R., Hanson, C., Ranganathan, J., Dumas, P., Matthews, E., Klirs, C. 2019. Creating a sustainable food future: A menu of solutions to feed nearly 10 billion people by 2050. Final report. WRI.

Singh, M., Kumar, J., Singh, V. P., Prasad, S. M., 2014. Plant tolerance mechanism against salt stress: the nutrient management approach. Biochem. Pharmacol, 3: e165.

Qiu, R., Yang, Z., Jing, Y., Liu, C., Luo, X., Wang, Z., 2018. Effects of irrigation water salinity on the growth, gas exchange parameters, and ion concentration of hot pepper plants modified by leaching fractions. HortScience, 53(7): 1050-1055.

Qiu, R., Liu, C., Li, F., Wang, Z., Yang, Z., Cui, N., 2019. An investigation on possible effect of leaching fractions physiological responses of hot pepper plants to irrigation water salinity. BMC Plant Biology, 19(1): 297.

Tanveer, K., Gilani, S., Hussain, Z., Ishaq, R., Adeel, M., Ilyas, N., 2020. Effect of salt stress on tomato plant and the role of calcium. Journal of Plant Nutrition, 43(1): 2835.https://doi.org/10.1080/01904167.2020.1771587.

Tuna, A. L., Kaya, C., Ashraf, M., Altunlu, H., Yokas, I., Yagmur, B., 2007. The effects of calcium sulphate on growth, membrane stability and nutrient uptake of tomato plants grown under salt stress. Environmental and Experimental Botany, 59(2): 173-178.

Ünlükara, A., Kurunç, A., Kesmez, G. D., Yurtseven, E., 2008. Growth and evapotranspiration of okra (Abelmoschus esculentus L.) as influenced by salinity of irrigation water. Journal of irrigation and drainage engineering, 134(2): 160-166.

Ünlükara, A., Kurunç, A., Kesmez, G. D., Yurtseven, E., Suarez, D. L., 2010. Effects of salinity on eggplant (Solanum melongena L.) growth and evapotranspiration. Irrigation and Drainage: The journal of the International Commission on Irrigation and Drainage, 59(2): 203-214.

Vuchkov, I.N., Boyadjieva, L.N., 2001. Quality 1mprovement with design of experiments: a response surface approach, Kluwer Academic Publishers, Netherlands.

Wang, H., Li, J., Cheng, M., Zhang, F., Wang, X., Fan, J., Wu, J., Fang, D., Zou, H., Xiang, Y. (2019). Optimal drip fertigation management improves yield, quality, water and nitrogen use efficiency of greenhouse cucumber. Scientia Horticulturae, 243: 357-366.

Zandalinas, S. I., Mittler, R., Balfagón, D., Arbona, V., Gómez-Cadenas, A., 2018. Plant adaptations to the combination of drought and high temperatures. Physiologia plantarum, 162(1): 2-12. 